\title{
Melanoma of the Iris pT4b TNM Finding v7
}

National Cancer Institute

\section{Source}

National Cancer Institute. Melanoma of the Iris pT 4b TNM Finding v7. NCI Thesaurus.

Code C88682.

Melanoma of the iris with extrascleral extension more than $5 \mathrm{~mm}$ in diameter. (from AJCC 7th Ed.) 